\title{
HTA and innovative treatments evaluation: the case of metastatic castration-resistant prostate cancer [Corrigendum]
}

Bretoni A, Ferrario L, Foglia E. Clinicoecon Outcomes Res. 2019;11:283-300.

The authors of this paper have advised us that there is a typographical error in one of the headings in Table 4.
Table 4 occupies two pages and while being continued from page 292 onto page 293, a wrong table header was recorded. The table heading "Effectiveness profile" should instead be replaced by "Equity aspects" on page 293 .

\section{Publish your work in this journal}

ClinicoEconomics and Outcomes Research is an international, peerreviewed open-access journal focusing on Health Technology Assessment, Pharmacoeconomics and Outcomes Research in the areas of diagnosis, medical devices, and clinical, surgical and pharmacologica intervention. The economic impact of health policy and health systems organization also constitute important areas of coverage. The manuscript management system is completely online and includes a very quick and fair peer-review system, which is all easy to use. Visit http://www.dovepress.com/testimonials.php to read real quotes from published authors. 